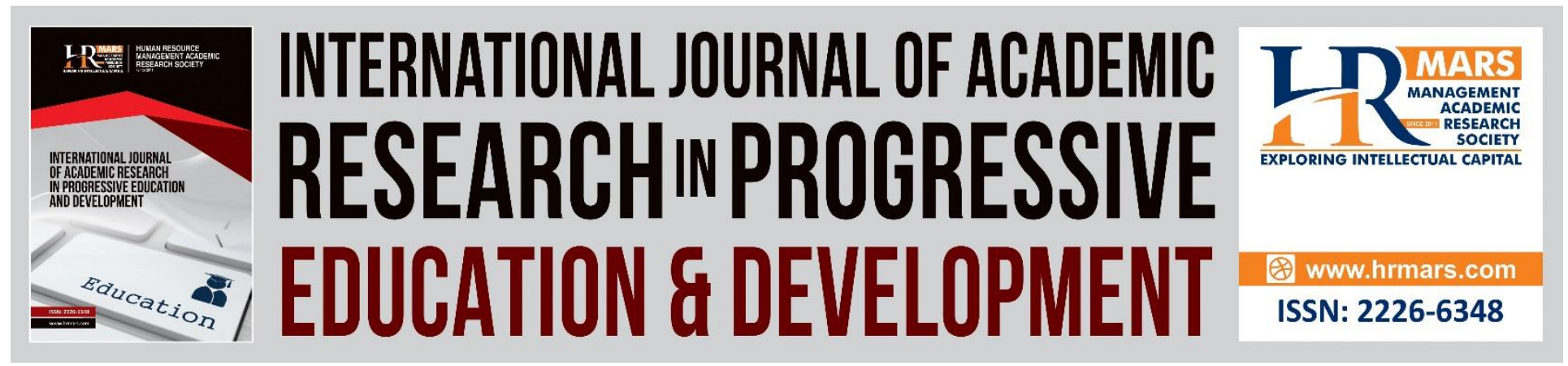

\title{
A Powerful of Digital Storytelling to Support Education and Key Elements from Various Experts
}

Kogila, M., Abu Bakar Ibrahim and Che Zalina Zulkifli

To Link this Article: http://dx.doi.org/10.6007/IJARPED/v9-i2/7483

DOI:10.6007/IJARPED/v9-i2/7483

Received: 11 March 2020, Revised: 13 April 2020, Accepted: 10 May 2020

Published Online: 27 June 2020

In-Text Citation: (Kogila et al., 2020)

To Cite this Article: Kogila, M., Ibrahim, A. B., \& Zulkifli, C. Z. (2020). A Powerful of Digital Storytelling to Support Education and Key Elements from Various Experts. International Journal of Academic Research in Progressive Education and Development, 9(2), 408-420.

Copyright: (C) 2020 The Author(s)

Published by Human Resource Management Academic Research Society (www.hrmars.com)

This article is published under the Creative Commons Attribution (CC BY 4.0) license. Anyone may reproduce, distribute, translate and create derivative works of this article (for both commercial and non-commercial purposes), subject to full attribution to the original publication and authors. The full terms of this license may be seen at: http://creativecommons.org/licences/by/4.0/legalcode

Vol. 9(2) 2020, Pg. 408 - 420

http://hrmars.com/index.php/pages/detail/IJARPED

JOURNAL HOMEPAGE

Full Terms \& Conditions of access and use can be found at http://hrmars.com/index.php/pages/detail/publication-ethics 


\title{
LR \\ INTERNATIONAL JOURNAL OF ACADEMIC \\ RESEARCHINPROGRESSIVE \\ EDUCATION \& DEVELOPMENT

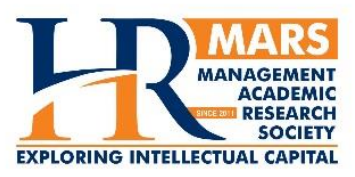 \\ INTERNATIONAL JOURNAL
OF ACADEMIC RESEARCH
IN PROGRESSIUE EDUCATIO \\ IN PROGRESSIVE E
AND DEVELOPMENT \\ . \\ A Powerful of Digital Storytelling to Support Education and Key Elements from Various Experts
}

\author{
Kogila, M. ${ }^{1}$, Abu Bakar Ibrahim ${ }^{2}$ and Che Zalina Zulkifli ${ }^{3}$ \\ Faculty of Arts, Computing and Creative Industry, Sultan Idris Education University \\ 35900 Tanjung Malim, Perak, Malaysia \\ Email: kogila.ko@yahoo.com, abubakar.ibrahim@fskik.upsi.edu.my, \\ chezalina@fskik.upsi.edu.my
}

\begin{abstract}
Technological devices are commonly used in different styles and for several uses with educational systems. Instructors have to avoid using technology together with the utmost effectiveness but to additionally serve as role models for pupils in regards to the correct use of technology. Different methods, strategies, equipment, along with tools are used to enhance the effectiveness of coaching and learning operations in the classroom, of that Digital Storytelling is among them. Digital Storytelling (DST) has transformed into a good educational tool for both students and teachers. This paper offers a review of DST as well as portrays where it originated from, how it really well may be utilized to help guide as well as how understudies that discover the way to whip their own advanced stories improve a lot of instruction abilities. What's more often, info is shown about the device which might be utilized to help the instructive utilization of DST. This paper, in addition, has a discussion on the usefulness of DST as being an instructional media program employed in the education process. The goal of this paper is to present the main components of DST used by specialists in DST concepts. This study also discussed the overview of DST combined with the learning atmosphere, particulars specific DST modals and determined the essential elements of DST from several experts to be able to centralize them to cultivate the framework with support different ICT technology. Moreover, the paper covers the justification for the selection of past studies related to main important elements of DST.
\end{abstract}

Keywords: Multimedia, Instructional Media, Digital Storytelling, Education.

\section{Introduction}

Digital storytelling (DST) fuses the craft of recounting profiles developing a mix of electronic press, like textual content, pictures, captured great portrayal, video, and music. These media elements are mixed together, utilizing computer programming to recount a story that often rotates around a particular theme or subject and also generally includes a specific point of view. Most digital stories are usually, gentle with a length of anywhere in the assortment of 2 and 10 minutes, plus are spared within a sophisticated setup which might be found on a 
computer or other gadget equipped for taking part in video captures. Furthermore, digital stories are often transferred straight into the intrigue, wherever they may be observed through any popular internet browser. You will find different types of innovative accounts; nevertheless, the creator has suggested arranging the considerable types into the accompanying 3 classifications: 1) particular stories - stories that have data of noteworthy attacks across one 's life; 2) verifiable narratives - accounts which inspect sensational events that help us with comprehension days gone by, and 3) stories which guide or even teach the advanced narrating joins the craft of recounting accounts with a combination of electronic media, such as text, photographs, recorded good portrayal, video (Robin and music, 2006). These media segments are mixed by using computer programming, to relate to a story which commonly pivots around a certain topic or subject and habitually incorporates a specific viewpoint. Most digital stories are usually, light with a length of anywhere in the assortment of two and ten minutes, and also are spared within an advanced setup which may be observed on other gadget or a PC equipped for participating in video captures. Additionally, digital stories are frequently transferred into the intrigue, where they might be seen through any popular Internet browser. DST has relentlessly produced in prominence and it is at present getting polished in a pile of areas, like facilities, libraries, public venues, historic centers, regenerative along with nursing schools, businesses and that is just the idea of the iceberg.

\section{Instructional Media}

Studies have inspected the significance of Instructional Media (IM) for successful study hall educating furthermore, learning. Fidanboylu (2014) contends that the utilization of visual guides in educating can spur the understudies and fortify the subject substance. Makewa, Role and Ngussa (2012) noticed that media assets are significant with regards to guidance. They contend that instructional assets are imperative to the instructing of any subject. As indicated by Seth (2009), the absence of divider diagrams, models and other ordinary media to commend the utilization of writing slates and reading material in the schools expanded hard for educators to offer quality instructing and learning to advance high scholarly execution for middle school's understudies in Ghana. Numerous creators have analyzed the noteworthiness of utilizing instructional media in educating/learning process. Wambura (2017) noticed that PC has numerous advantages in training, for instance: upgrading scholastic works, improving exercise and understudies understanding and impacting autonomous learning. As suggested by Karanja (2015), learning and educating property are crucial in education because they rouse as well as urge pupils to use numerous senses, henceforth growing the concern of theirs and upkeep restrict. What's more often, educating and learning assets produce inspiration in mastering (Monda, 2012).

Media instructional teaching is among the key parts of the system instructional design (Gamor and Holden, 2010). Media teaching is also a platform for delivering the message, stimulating, motivating, students' attention and lead to effective learning (Rafiza \& Mary, 2013; Rian \& Kasimah, 2013). The teaching media category is split into 2 groups, media coaching classical and contemporary teaching media. Common types of teaching, blackboard, travel, dioramas, comics, cartoons, posters, images, templates, maps, magazines, including books, etc. Electric instructing aids, meanwhile, usually include efficient info, video clip clip, a stereo system, 
cell phone, tv, computer, projection info, the web together with extra electric media (Isman, 2011).

Digital story making in the classroom is a good teaching tool that has the possibility to transform pupil learning. Internet stories are lightweight as they're stored by digital computers and messages and are exchanged. This allows the teachers to archive the job process and outcome of the pupil while permitting the understudies to find crafted by others (Alonso et al.,2013).

\section{Storytelling}

Through the story of social and human development, storytelling is used as something for the transmission as well as sharing of values and knowledge, since it's a natural and yet impressive strategy to communicate and exchange experiences and knowledge. One of the researcher reported, storytelling is a process whereby students personalize what they discover and construct their very own knowledge and meaning out of the stories they pick up and explain to (Behmer, 2005).

Based on Normann, people have usually told stories. It's been a part of our heritage and tradition since the time we gathered around the flame to discuss the stories of ours. Today people still explain to stories, but now we've brand new media tools with which to talk about them. An electronic story can thus be seen as a merger between the existing storytelling tradition as well as the utilization of technology that is new (Normann, 2011). To some extent, the application and traditional storytelling of personal computer technologies in training have observed diverse paths today (Banaszewski, 2005). Hence, there's a need to further improve the convergence of storytelling as well as the use of computer systems in the classroom. It's been argued that technology is much more useful when it's utilized during a wider academic enhancement agenda (Pitler, 2006).

Fortuitously, with the increased laptop strength and connected cost reduction, related technologies and computers are able to perform a major part in creating storytelling a far more popular pedagogical tool, since Digital storytelling provides pupils with a good base in what exactly is getting referred to as 21st Century Skills' (Miller, 2009). While vital technology is currently accessible within the classroom, storytelling hasn't been completely recognized as an invaluable tool for building students' learning abilities and getting 21 st-century learning results.

\section{Digital Storytelling (DST)}

Innovation is a quick pace advancement and it influences numerous parts of life and various spaces. One of the areas influenced by innovation by and large or interactive media explicitly is narrating. Well before the introduction of innovation, conventional narrating is communicated in its most essential structures, which are orally or composed. Be that as it may, the presentation of interactive media has changed the point of view of narrating in another manner. Digital storytelling (DST) is one of the products of innovation. As indicated by Porter (2004), advanced narrating consolidates the specialty of customary narrating with interactive media components, for example, pictures, illustrations, music, and sound so as to make an actually voiced story. Concerning Robin (2008a), he expresses that advanced narrating is a mix of the specialty of narrating with various digital media, for example, sound, video, and realistic. Whatever the 
meanings of advanced narrating, it is irrefutable this new type of narrating is partaking in the realm of digital correspondence in numerous territories and it is digging in for the long haul.

Transition storytelling in the digital form involving injections of multimedia technology is the result of a collaborative partnership by Joe Lambert and Dana Atchley to develop effective narrative delivery, better known as DST (Signes, 2010). The difference in the views of experts who translate DST has led to various definitions of Digital Storytelling. Robin (2006) has described the art of storytelling DST as a combination of digital multimedia elements such as graphics, text, audio recordings, and music to view relevant topic-oriented content. Porter (2008b) and Ohler (2008) also revealed DST as the combination of the traditional art of storytelling verbally with multimedia technology equipment by using images, graphics, music and sound as well as voice narrator with creativity and audience interaction to meet the satisfaction of delivering storytelling. In the book of his Digital Storytelling: A Creator's Guide to Interactive Entertainment, Miller (2008), declared DST is a narrative amusement of the industry to have interaction through media and technology. Lambert (2010) has realized that DST is a brief story, footage narrative made by a combination of soundtracks, pictures, music or sound, video and animation.

\section{Key Elements Digital Storytelling from experts and limitation}

Storytelling elements meant to distinguish DST together with some other media like film, television, video and blogs (Lowenthal, 2006). This's since the market is interested in continuing to pay attention to the story content is determined by the component of storytelling. Table 1 outlines a variety of elements to understand the concept of DST from the perspective of different specialists. These elements need to be improved to support the research needs in terms of technology and interactivity. 
INTERNATIONAL JOURNAL OF ACADEMIC RESEARCH IN PROGRESSIVE EDUCATION AND DEVELOPMENT

Vol. 9, No. 2, 2020, E-ISSN: 2226-6348 @ 2020 HRMARS

\begin{tabular}{|c|c|c|c|}
\hline EXPERTS & ELEMENTS & & LIMITATION \\
\hline $\begin{array}{l}\text { PORTAR } \\
(2004)\end{array}$ & $\begin{array}{l}\text { - Living in your story } \\
\text { - Unfolding lessons } \\
\text { learning } \\
\text { - Developing creative } \\
\text { tension } \\
\text { - Economizing the } \\
\text { story told } \\
\text { - }\end{array}$ & $\begin{array}{l}\text { - Showing not } \\
\text { telling } \\
\text { - Developing } \\
\text { craftsmanship }\end{array}$ & $\begin{array}{l}\text { - Less interactivity with the } \\
\text { story } \\
\text { - Limited technology such as } \\
\text { multimedia, hardware and } \\
\text { tools } \\
\text { - Linear } \\
\text { - One-way communication }\end{array}$ \\
\hline $\begin{array}{l}\text { LAMBERT } \\
(2006)\end{array}$ & $\begin{array}{l}\text { - A point of view } \\
\text { - A dramatic question } \\
\text { - Emotional content } \\
\text { - The gift of your voice }\end{array}$ & $\begin{array}{l}\text { - The power of the } \\
\text { soundtrack } \\
\text { - Economy } \\
\text { - Pacing }\end{array}$ & $\begin{array}{l}\text { - Less clear with hardware } \\
\text { technology requirements } \\
\text { - Less interactive } \\
\text { - Less obvious technology } \\
\text { (multimedia, hardware, } \\
\text { software) used }\end{array}$ \\
\hline $\begin{array}{l}\text { ROBIN } \\
(2008)\end{array}$ & $\begin{array}{l}\text { - The overall purpose } \\
\text { of the story } \\
\text { - The narrator's point } \\
\text { of view } \\
\text { - Quality of the } \\
\text { images, video \& } \\
\text { other } \\
\text { - multimedia } \\
\text { elements }\end{array}$ & $\begin{array}{l}\text { - The choice of } \\
\text { content } \\
\text { - The pacing of the } \\
\text { narrative } \\
\text { - Good grammar } \\
\text { and language } \\
\text { usage } \\
\text { - Clarity of voice }\end{array}$ & $\begin{array}{l}\text { - Less clear with hardware } \\
\text { technology requirements } \\
\text { - Less interactive with } \\
\text { multimedia elements } \\
\text { - Less interactivity with the } \\
\text { story } \\
\text { - Less clarity with the audio } \\
\text { and voice }\end{array}$ \\
\hline $\begin{array}{l}\text { OHLER } \\
(2008)\end{array}$ & $\begin{array}{l}\text { - Point of view } \\
\text { - Emotional } \\
\text { engagement } \\
\text { - Tone } \\
\text { - Spoken narrative } \\
\text { - Soundtrack music }\end{array}$ & $\begin{array}{l}\text { - Role of video and } \\
\text { performance } \\
\text { - Creativity and } \\
\text { originality } \\
\text { - Time, story length } \\
\text { and economy }\end{array}$ & $\begin{array}{l}\text { - Less clear with hardware } \\
\text { technology requirements } \\
\text { - Less interactive with } \\
\text { graphic elements. } \\
\text { - Less interactivity with the } \\
\text { story }\end{array}$ \\
\hline $\begin{array}{l}\text { KUAN ET, } \\
\text { AL. } \\
(2012)\end{array}$ & $\begin{array}{l}\text { - Intension } \\
\text { - Dramatical question } \\
\text { - Soundtrack } \\
\text { - Story track } \\
\text { - Story map }\end{array}$ & $\begin{array}{l}\text { - Significant } \\
\text { Content } \\
\text { - Personal } \\
\text { - Engagement } \\
\text { - Expression }\end{array}$ & $\begin{array}{l}\text { - Less interactive with } \\
\text { graphic elements. }\end{array}$ \\
\hline
\end{tabular}

Table 1: List of key elements of DST 
INTERNATIONAL JOURNAL OF ACADEMIC RESEARCH IN PROGRESSIVE EDUCATION AND DEVELOPMENT

Vol. 9, No. 2, 2020, E-ISSN: 2226-6348 @ 2020 HRMARS

\section{Past studies Related Elements of DST}

A content analysis involving eight samples because the storytelling of previous studies has been carried out to identify some element DST. It also involves the design principle of the support element DST, as shown in Table 2.

Table 2: Justification for the selection of past studies related element of DST

\begin{tabular}{|c|c|c|c|}
\hline $\begin{array}{l}\text { SOURCE/ } \\
\text { STORYTELLING }\end{array}$ & JUSTIFICATION OF STUDY & $\begin{array}{l}\text { ELEMENT DST/ } \\
\text { DESIGN } \\
\text { PRINCIPLES }\end{array}$ & \\
\hline $\begin{array}{l}\text { SHIN, KIM DAN } \\
\text { PARK, } \\
\text { (2005) } \\
\text { AR STORYBOARD }\end{array}$ & $\begin{array}{l}\text { Studies have suggested eight } \\
\text { elements of narrative } \\
\text { storytelling because, according } \\
\text { to the understanding and } \\
\text { enjoyment of users. }\end{array}$ & $\begin{array}{l}\text { - Layout Object } \\
\text { - Scene } \\
\text { - Visual text } \\
\text { - Interactivity }\end{array}$ & $\begin{array}{l}\text { - Transition } \\
\text { - Character } \\
\text { - Articulation } \\
\text { - Realistic }\end{array}$ \\
\hline $\begin{array}{l}\text { YU et al. } \\
\text { (2009) } \\
\text { INTERACTIVE } \\
\text { STORYBOARD }\end{array}$ & $\begin{array}{l}\text { The study aims to help novice } \\
\text { designers with seven elements } \\
\text { to produce a prototype } \\
\text { because of storytelling in a } \\
\text { simple, efficient and enhance } \\
\text { the creativity of the designer }\end{array}$ & $\begin{array}{l}\text { - Interaction } \\
\text { touch screen } \\
\text { - Interactivity } \\
\text { - Character }\end{array}$ & $\begin{array}{l}\text { - Object } \\
\text { - Scenes } \\
\text { - Narrative } \\
\text { content }\end{array}$ \\
\hline $\begin{array}{l}\text { BIDWELL, } \\
\text { REITMAIER, } \\
\text { MARSDEN DAN } \\
\text { HANSEN, } \\
(2010) \\
\text { MOBILE } \\
\text { MULTIMEDIA } \\
\text { PRESENTATION }\end{array}$ & $\begin{array}{l}\text { The study tested the } \\
\text { effectiveness of the eight } \\
\text { elements of the interface } \\
\text { because of storytelling with } \\
\text { mobile devices. }\end{array}$ & $\begin{array}{l}\text { - The touch } \\
\text { screen } \\
\text { interaction } \\
\text { - Icon } \\
\text { - Collaborative } \\
\text { - Editing }\end{array}$ & $\begin{array}{l}\text { - Articulation } \\
\text { - Audio } \\
\text { - Content } \\
\text { narrative } \\
\text { - Purpose }\end{array}$ \\
\hline $\begin{array}{l}\text { CHANG \& } \\
\text { BREAZEAL, } \\
\text { (2011) } \\
\text { THINKRBOOK }\end{array}$ & $\begin{array}{l}\text { The study aims to encourage } \\
\text { the habit of reading among } \\
\text { children by involving the six } \\
\text { elements of touch screen } \\
\text { interaction in storytelling } \\
\text { tools. }\end{array}$ & $\begin{array}{l}\text { - The } \\
\text { interaction of } \\
\text { the touch } \\
\text { screen } \\
\text { - Articulation } \\
\text { - Interactivity }\end{array}$ & $\begin{array}{l}\text { - Structure of } \\
\text { narrative } \\
\text { - Animation } \\
\text { - Content of } \\
\text { the story }\end{array}$ \\
\hline $\begin{array}{l}\text { ATOSOY \& } \\
\text { MARTENS, } \\
\text { (2011) } \\
\text { STORIFY }\end{array}$ & $\begin{array}{l}\text { Studies have identified five } \\
\text { elements to build } \\
\text { communication skills and } \\
\text { strategies in storytelling } \\
\text { experience with storytelling } \\
\text { tools to help designers. }\end{array}$ & $\begin{array}{l}\text { - Interactivity } \\
\text { - Character } \\
\text { - Beat story }\end{array}$ & $\begin{array}{l}\text { - Audio music } \\
\text { - Scenes }\end{array}$ \\
\hline
\end{tabular}


INTERNATIONAL JOURNAL OF ACADEMIC RESEARCH IN PROGRESSIVE EDUCATION AND DEVELOPMENT

Vol. 9, No. 2, 2020, E-ISSN: 2226-6348 @ 2020 HRMARS

\begin{tabular}{|c|c|c|c|}
\hline $\begin{array}{l}\text { BONGSHIN et al. } \\
\text { (2013) } \\
\text { SKETCHSTORY }\end{array}$ & $\begin{array}{l}\text { The study involved seven } \\
\text { elements touch screen } \\
\text { interaction with mobile } \\
\text { devices because of storytelling } \\
\text { to encourage audience } \\
\text { participation in DST. }\end{array}$ & $\begin{array}{l}\text { - The } \\
\text { involvement } \\
\text { of the } \\
\text { audience } \\
\text { - Interaction of } \\
\text { touch screen } \\
\text { - icon }\end{array}$ & $\begin{array}{l}\text { - Interactivity } \\
\text { - Expression } \\
\text { - Narrative } \\
\text { - Graphic }\end{array}$ \\
\hline $\begin{array}{l}\text { YUKSEL.P,YILDIRIM } \\
\text { \& ROBIN.R.B } \\
(2016)\end{array}$ & $\begin{array}{l}\text { The study aims to support the } \\
\text { use of technology in early } \\
\text { childhood teaching. }\end{array}$ & $\begin{array}{l}\text { - Student } \\
\text { Collaborative } \\
\text { - Narrative } \\
\text { - Technology } \\
\text { - Interactivity }\end{array}$ & $\begin{array}{l}\text { - } \text { Multimedia } \\
\text { - Learning } \\
\text { process } \\
\text { - Audio music }\end{array}$ \\
\hline $\begin{array}{l}\text { HASHIROH } \\
\text { HUSSAIN } \\
\text { (2017) } \\
\text { DIGITAL } \\
\text { STORYTELLING } \\
\text { CONCEPT FOR } \\
\text { TOUCH SCREEN } \\
\text { TABLET }\end{array}$ & $\begin{array}{l}\text { The study identified nine } \\
\text { elements touch screen tablet } \\
\text { to design the framework for } \\
\text { digital storytelling. }\end{array}$ & $\begin{array}{l}\text { - Interaction } \\
\text { touch screen } \\
\text { - Interactivity } \\
\text { - Character } \\
\text { - Object } \\
\text { - Scenes } \\
\text { - Narrative } \\
\text { content }\end{array}$ & $\begin{array}{l}\text { - Functional } \\
\text { dimension } \\
\text { - Collaborative } \\
\text { - Audio music } \\
\text { - Story beats } \\
\text { - Originality }\end{array}$ \\
\hline $\begin{array}{l}\text { VINAYAKUMAR.R, } \\
\text { KP SONAN, } \\
\text { MENON.P } \\
\text { (2018) } \\
\text { DIGITAL } \\
\text { STORYTELLING } \\
\text { (DST) USING } \\
\text { SCRATCH }\end{array}$ & $\begin{array}{l}\text { This analysis explores the DST } \\
\text { much more fascinating and } \\
\text { unforgettable for kids. DST is } \\
\text { recognized as being a } \\
\text { motivating instructional } \\
\text { strategy which engages the } \\
\text { learner in } 21 \text { st century } \\
\text { learning skills. }\end{array}$ & $\begin{array}{l}\text { - Interaction of } \\
\text { mobile } \\
\text { technology } \\
\text { - Narrative } \\
\text { content } \\
\text { - Audio music } \\
\text { - Video content }\end{array}$ & $\begin{array}{l}\text { - 3D animation } \\
\text { - Technology } \\
\text { block-based } \\
\text { programming. } \\
\text { - Text, scenes } \\
\text { \& character }\end{array}$ \\
\hline
\end{tabular}

\section{Digital Storytelling in Education}

There are many ways that DST could be utilized in education. One of the primary decisions being done when choosing to make use of this device within the curriculum is whether a teacher can create the Digital Stories or even have their pupils do it. A number of educators might want to produce their own stories of theirs and show them to the students of theirs as a means to provide new material. An engaging, multimedia-rich digital story is able to serve as an anticipatory established or maybe hook to capture the interest of pupils and to raise the interest of theirs in exploring new ideas.

The teacher created digital stories can be applied to boost the latest lessons within a larger device, as a means to facilitate talk about a story was presented by the topics and as a means of making conceptual or abstract content even more understandable. Even though many educators continue to miss a cohesive for integrating multimedia into the instruction of theirs, an expanding number of instructors are excited about exploring ways to engage the students of 
theirs by adding images, sound and video components in their instruction. Study indicates the usage of multimedia in teaching will help pupils retain information that is new, along with aids within the comprehension of hard material.

An educator can make the digital stories and create their own accounts of theirs and demonstrate them to the understudies of theirs as an approach to display brand new material. A joining with media rich digital story is able to fill up in as an expectant established or maybe snare in order to capture the consideration of understudies and to grow the enthusiasm of theirs for investigating brand new thoughts. Various analysts strengthen the utilization of expectant sets to the beginning of a workout to help you visit understudies in the learning process (Burmark, 2004; Ormrod, 2004) and also as a scaffold between current new material and information (Ausbel, 1978).

Educator made advanced stories may likewise be used improving latest exercises inside a larger device, as a method of inspiring discussion about a story was introduced by the subjects and as a technique to make theoretical or dynamic substance increasingly reasonable while many coaches, despite whatever, do not have a good for corresponding diverse press into the assistance of theirs, an expanding number of educators are clear on looking into methods to make the understudies of theirs by incorporating pictures, sound in addition to video components within the direction of theirs. Hibbing and Rankin-Erikson (2003) and Boster, Meyer, Toberto, and the Inge (2002), have recommended the utilization of effective press in displaying helps understudies withholding information that is new just as can help inside the appreciation of troublesome material. Additionally, DST is able to provide teachers an amazing advantage to utilize inside their learn halls.

\section{Conclusion}

DST refers to a technology enhanced activity of using digital tools for the story creation (Williams, 2014). Stories are able to tranfer meaning in greater speed than the intellect alone since audience's emotions. Thus, DST is a good tool for creating learning environments based on constructionist principles of teaching and learning. It is the potential to engage learners in integrated approaches to learning with electronic media. There are a lot more advantages that DST can serve in training that it surpasses the limit of this research paper. From the critiques on entire DST elements and also the impact of DST on pupil learning, the outcomes of the research will enable both students and teachers to take advantage of the power of DST and more engaged teaching and learning process. The research focused on how the DST support the education system and dissuss about the main elements by various experts and modified the elements to support the new technology education system.

\section{References}

Abbott, H. P. (2002). The Cambridge introduction to narrative. United Kingdom: Cambridge University Press. Retrieved from http://catdir.loc.gov/catdir/samples/cam031/2001037549.pdf

Alonso, I., Molina, S., and Requejo, M. D. P. (2013). Multimodal digital storytelling: Integrating information, emotion and social cognition. Rev. Cogn. Linguist. 11, 369-387. DOI: 10.1075/rcl.11.2.10alo 
INTERNATIONAL JOURNAL OF ACADEMIC RESEARCH IN PROGRESSIVE EDUCATION AND

DEVELOPMENT

Vol. 9, No. 2, 2020, E-ISSN: 2226-6348 @ 2020 HRMARS

Atasoy, B., \& Martens, J.-B. (2011). Crafting user experiences by incorporating dramaturgical techniques of storytelling. Proceedings of the Second Conference on Creativity and Innovation in Design - DESIRE '11, 91. https://doi.org/10.1145/2079216.2079230

Ausubel, D. P. (1978). In defense of advance organizers: A reply to the critics. Review of Educational Research, 48, 251-257.

Bidwell, N. J., Reitmaier, T., Marsden, G., \& Hansen, S. (2010). Designing with mobile digital storytelling in rural Africa. In Proceedings of the 28th international conference on Human factors in computing systems - CHI'10 (p. 1593). New York, USA: ACM Press. https://doi.org/10.1145/1753326.1753564

Bongshin, L., Rubaiat, H. K., \& Smith, G. (2013). SketchStory: Telling more engaging stories with data through freeform sketching. IEEE Transactions on

Boster, F. J., Meyer, G. S., Roberto, A. J., \& Inge, C. C. (2002). A report on the effect of the United Streaming application on educational performance. Farmville, VA: Longwood University.

Burmark, L. (2004). Visual presentations that prompt, flash \& transform. Media and Methods, 40(6).

Chang, A., \& Breazeal, C. (2011). TinkRBook: Shared reading interfaces for storytelling. In Proceedings of the 10th International Conference on Interaction Design and Children (pp. 145-148). New York, USA: ACM New York.

Fidanboylu, K. (2014). Teaching Language with Visual Aids. Retrieved from https://colorsofteaching.wordpress.com/about/

Hibbing, A. N., \& Rankin-Erikson, J. L. (2003). A picture is worth a thousand words: Using visual images to improve comprehension for middle school struggling readers. Reading Teacher, 56(8), 758.

Holden, J. T., \& Gamor, K. I. (2010). An instructional media selection guide for distance learning (Second Edi). United States of America: United States Distance Learning Association.

Hussain, H., \& Shiratuddin, N. (2017). Designer Perception Towards Quality Guideline For The Development of Instructional Media With Digital Storytelling Concept for Touch Screen Tablet. Malaysian Journal of Learning and Instruction, 14., pp. 271-292.

Isman, A. (2011). Instructional design in education: New model. Turkish Online Journal of Educational Technology - TOJET, 10(1), 136-142. Retrieved from http://eric.ed.gov/?q=(+Lesson+plan+OR+lesson+planning+)

+AND+(+behaviorism+OR+cognitivism+OR+constructivism+)\&ff1=pubJournal+Articles\&id=EJ 926562

Karanja, P. M. (2015). Management of Teaching and Learning Resources in Primary Schools in Kandara Division, Kandara District, Muranga County, Kenya. Master of Education Unpublished Dissertation, Kenyatta University.

Lambert, J. (2010). Digital storytelling cookbook. Seven steps of digital storytelling (pp. 9-24). Berkeley, CA: Digital Diner Press. Retrieved from http://static.squarespace.com/static/505a3ab2e4b0f1416c7df69a/t/ 51c3458be4b096e91f04d680/1371751819981/cookbook_sample.pdf

Lowenthal, P. (2006). Digital storytelling: An emerging institutional technology? In Story circle: Digital storytelling around the world (pp. 297-305). Wiley-Blackwell. 
Makewa, L. N., Role, E., Ngussa, B. (2012). The usefulness of Media Resources in English Instruction: A Case of Adventist secondary schools in Tanzania. J. Educ. Pract., 3(15):163172

Miller, C. H. (2008). Digital storytelling: A creator's guide to interactive entertainment (Second Edi). Burlington, USA: Focal express.

Monda, T. M. (2012). Influence of Teaching and Learning Materials on Children Performance in Preschools in Borabu district, Nyamira County, Kenya. Master of Education Unpublished Dissertation, University of Nairobi

Ohler, J. (2008). Digital storytelling in the classroom new media pathways to literacy, learning, and creativity (Second Edi). United States of America: SAGE Publications, Inc. Retrieved from http://www.amazon.com/Digital-Storytelling-Classroom-PathwaysCreativity/dp/1452268258

Ormrod, J. E. (2004). Human learning (4th ed.). Upper Saddle River, NJ: Pearson Educational, Inc.

Porter, B. (2004). About digital storytelling. Retrieved 12 August 2008, from http://www.digitales.us/about/ index.php

Porter, B. (2008b). Digital storytelling across the curriculum, finding content's deeper meaning. The Creative Educator, 7-9.

Rafiza, A. R., \& Maryam, A. R. (2013). Pembinaan media pengajaran berasaskan multimedia di kalangan guru ICTL. Jurnal Kurikulum \& Pengajaran Asia Pasifik, 1(2), 20-31.

Rian, V., \& Kamisah, O. (2013). Keberkesanan penggunaan pelbagai media pengajaran dalam meningkatkan kemahiran proses sains dalam kalangan pelajar. Jurnal Pendidikan Malaysia, 37(1), 1-11.

Robiatul A'dawiah, J., \& Halimah, Z. B. (2011). Pembangunan perisian Cerita animasi interaktif Untuk Pendidikan sains. Jurnal Teknologi Pendidikan Malaysia, 1, 5-18. Retrieved from http://www.jtpm-meta.com/resources/141 - JTPM V1N4 - 2011 - Rabiatul - 1.pdf

Robin, B. (2008a). Digital storytelling: A powerful technology tool for the 21st-century classroom. Theory into Practice, 47(3), 220-228.

Robin, B. R. (2006). The educational uses of digital storytelling. In Proceedings of Society for Information Technology and Teacher Education International Conference (pp. 709-716). Chesapeake, VA: AACE. Retrieved from http://www.coe.uh.edu/digital

R.Robin, B., \& Mcneil, S. G. (2019). Digital Storytelling. The International Encyclopedia of Media Literacy. DOI:10.1002/9781118978238.ieml0056

Sonan, R. V. K., \& Menon, P. (2018). Digital storytelling using Scratch: Engaging children towards digital storytelling. IISC, Bengaluru: 9th ICCCNT, 2018.

Seth, O. K. (2009). Instructional Media as a Tool for Ensuring Quality Teaching and Learning for in the Junior High Schools (Selected schools in the Kumasi Metropolis). Master of Education Unpublished Dissertation, Kwame Nkrumah University of Science and Technology, Kumasi).

Shin, M., Kim, B., \& Park, J. (2005). AR storyboard: An augmented reality-based interactive storyboard authoring Tool. In Proceedings of the International Symposium on Mixed and Augmented Reality (ISMAR'05) (pp. 1-2). IEEE Computer Society.

Signes, C. G. (2010). Practical uses of digital storytelling. Universität de Valencia. 
INTERNATIONAL JOURNAL OF ACADEMIC RESEARCH IN PROGRESSIVE EDUCATION AND

DEVELOPMENT

Vol. 9, No. 2, 2020, E-ISSN: 2226-6348@ 2020 HRMARS

Smeda, N., Dakich, E., \& Sharda, N. (2014). The effectiveness of digital storytelling in the classrooms: A comprehensive study. Smart Learning Environments, 1(1), 1-21. DOI: 10.1186/s40561-014-0006-3

Sova, R., \& Sova, D. H. (2011). Storyboards: A dynamic storytelling tool. Usability Professionals' Association Forum, UPA 2006. Usability Professionals Association. Retrieved from http://teced.com/wpcontent/uploads/2011/06/upa2006_storyboards_a_dynamic_story telling_tool.pdf

Tenh, H. K. (2013). Conceptual model of digital storytelling (DST). Universiti Utara Malaysia. Visualization and Computer Graphics, 19(12), 2416-25. https://doi.org/10.1109/TVCG.2013.191

Wambura, C. (2017). The Extent of Computer Usage among School Teachers and Students in Ilala Municipality, Dares Salaam. Master of Education Unpublished Dissertation, The Open University of Tanzania.

Williams, R. (2014). Keywords: A vocabulary of culture and society. Oxford University Press.

Yu, K., Wang, H., Liu, C., \& Niu, J. (2009). Interactive storyboard: Animated story creation on touch interfaces. In 5th International Conference Active Media Technology (pp. 93-103). Beijing, China: Springer Berlin Heidelberg. https://doi.org/10.1007/978-3-642-048753_14

Yuksel, P., Robin, B., \& McNeil, S. (2011). Educational uses of digital storytelling all around the world. In M. Koehler \& P. Mishra (Eds.), Proceedings of Society for Information Technology \& Teacher Education International Conference 2011 (pp. 1264-1271). Chesapeake, VA: Association for the Advancement of Computing in Education.

Yuksel-arslan, P., Yildirim, S., \& Robin, B. R. (2016). A phenomenological study: teacher's experiences of using digital storytelling in early childhood education. Educational Studies, 42(5), 427-445. https://doi.org/10.1080/03055698.2016.1195717

\section{Biographies}

Kogila d/o Muthu Samy is a second-year Ph.D. student in the Multimedia department at the Faculty of Arts, Computing and Creative Industry at Sultan Idris Education University, Malaysia. Her doctoral research investigates the developing the framework of Digital Storytelling using a mobile application for primary school students. she is a Lecturer in the Department of Polytechnic Malaysia. She had 13 years of professional teaching experience as academia in Computer Application courses and Engineering Mathematic courses in Polytechnic. She also has experience in research in the Instructional Media field. She has developed confidence and interest in researching and teaching areas to enhance creative Innovation in Multimedia, Instructional Media and Information Technology.

Abu Bakar Ibrahim*(correspondence author) is an Associate Professor in the Computing Department, Faculty of Arts, Computing and Creative Industry at Sultan Idris Education University, Malaysia. He is received a B.Sc. in Electrical Engineering and a Master's Degree from Universiti Teknologi Malaysia (UTM)in 1998 and 2000, respectively. He received a Ph.D. in Electronic Engineering (Communication) from Universiti Teknikal Malaysia Melaka (UTEM) in the years 2013. He had professional teaching experience in the development of Low Noise Amplifier 
(LNA), Radio Frequency Communication System, Instructional Technology, Engineering Mathematics, Wireless Communication and Engineering Education. He has developed confidence and interest in researching and teaching areas to enhance creative Innovation in Engineering, Science \& Technology.

Che Zalina Zulkifli*(correspondence author) is an Associate Professor in the Computing Department, Faculty of Arts, Computing and Creative Industry at Sultan Idris Education University, Malaysia. She had over 20 years of professional teaching experience as academia and active researcher in the Electronics \& Electrical Engineering, Information Technology, Embedded System, Industry Creative \& Networking area. Experience as a Test Engineer in the multinational company. Her research projects have collaborated with a multinational company and government agencies, which contributes to a network that leads to new ideas and concrete research projects. The developed automation projects that focused on Sensor Monitoring, Embedded System, Software, loT and Wireless Communication fields have been successfully adopted by the industry to date. A total of more than a million Ringgit has been generated as an income to the University mainly from the Research Grant, Commercialization of innovative research products and also the services as a principal consultant. Expertise in the agriculture sector with a new invention to improve crop production adopted high technology. She is sincerely dedicated to the very wise in the green project about recycling and reuse of waste. She has won several international awards and national awards. She has developed confidence and interest in researching and teaching areas to enhance creative Innovation in Engineering, Science \& Technology. 